\title{
New records of Gyraulus rossmaessleri (Gastropoda: Planorbidae) in the Czech Republic
}

\author{
LUBOŠ BERAN
}

Kokořiinnsko Protected Landscape Area Administration, Česká 149, CZ-27601 Mělník, Czech Republic, e-mail: lubos.beran@schkocr.cz

BERAN L., 2005: New records of Gyraulus rossmaessleri (Gastropoda: Planorbidae) in the Czech Republic. - Malacologica Bohemoslovaca 4: 3-4. Online serial at $<$ http://mollusca.sav.sk> 30-June-2005.

Populations of the freshwater snail Gyraulus rossmaessleri (Auerswald, 1852) (Gastropoda, Planorbidae) were found at 4 sites in the Meandry Smědé Nature Reserve (Northern Bohemia, Czech Republic). In Bohemia this species has not been found for last 25 years and the nearest localities with its known occurrence in the past are situated about $100 \mathrm{~km}$ to the south-west.

\section{Introduction}

Gyraulus rossmaessleri (Auerswald, 1852) is according to MEIER-BROOK (1983) an European species with very restricted Central European range but GLÖER (2002) mentioned holarctic distribution. In comparison with other species of genus Gyraulus this gastropod inhabits especially temporary pools and wetlands. Conchs of $G$. rossmaessleri are often similar to non-angled conchs of $G$. acronicus (A. Férussac, 1807) and dissection is useful and often necessary for determination.

\section{Distribution in the Czech Republic}

Gyraulus rossmaessleri is mentioned from the Czech Republic for the first time in MÁcHA (1963) from Silesia. Revision of material in different collections (National Museum of Prague, private collection of P. Kuchař - owner L.R. Kolouch) showed that this species occurred in the past also in NorthWestern Bohemia and in Eastern Bohemia (BERAN 2002). New sites with occurrence of this species in the Litovelské Pomoraví Protected Landscape Area (Central Moravia) mentioned BERAN (2000). Recently it is known from the Litovelské Pomoraví PLA (Central Moravia), Poodří PLA, Ostrava surroundings, Opava surroundings (all Silesia) (BERAN 2002). Distribution of this gastropod in the Czech
Republic in different periods is shown in BERAN (2002).

G. rossmaessleri in the Czech Republic inhabits different types of temporary wetlands - alder carrs, swamps overgrown with Glyceria spp., Carex spp., small temporary pools or canals in floodplain forest or meadows. All these types of wetlands are endangered especially outside of protected sites by different human activities (e.g., river regulation, soil draining).

\section{New records}

New sites with occurrence of $G$. rossmaessleri were found in the Meandry Smědé Nature Reserve (Northern Bohemia) near Czech - Poland border in 2004. These new sites are mentioned below. Data are as follows - geographical coordinates, code of the mapping field for faunistic grid mapping (cf. PRUNER \& MíKA 1996), name of the nearest settlement, description of the site, altitude, name of finder, number of collected individuals, date of investigation): $50^{\circ} 59^{\prime} 18^{\prime \prime} \mathrm{N}, 1^{\circ} 01^{\prime} 42^{\prime \prime}$ E, 5056, Filipovka, temporary ditch near border of Meandry Smědé NR $400 \mathrm{~m}$ from the railway station Filipovka, 235 m, L. Beran, 6 ex., 25 April 2004; $50^{\circ} 59^{\prime} 06^{\prime}$ N , 1501'24" E, 5056, Filipovka, sedge marsh $10 \mathrm{~m}$ outside of the Meandry Smědé NR 
about $500 \mathrm{~m}$ from the railway station Filipovka, $235 \mathrm{~m}$, L. Beran, 10 ex., 25 April 2004; 5059'08” N, 1501'34" E, 5056, Filipovka, 5056, swamp in the Meandry Smědé NR near ditch $600 \mathrm{~m}$ to the south from the railway station Filipovka, $235 \mathrm{~m}$, L. Beran, 3 ex., 25 April 2004; 5059'06” N, 1501'36" E, 5056, Filipovka, ditch about $100 \mathrm{~m}$ before its inflow to the Smědá River in the Meandry Smědé NR, 235 m, L. Beran, 4 ex., 1 January 2004. Dissection of selected specimen confirmed the previous determination according conchs.

At mentioned localities $G$. rossmaessleri was found together with Galba truncatula (O.F. Müller, 1774), Aplexa hypnorum (Linnaeus, 1758), Anisus leucostoma (Millet, 1813), Pisidium obtusale (Lamarck, 1818), and P. casertanum (Poli, 1791).

In Bohemia this species has not been found for last 25 years and the nearest localities with its known occurrence more than 25 years ago are situated about $100 \mathrm{~km}$ to the south-west.

\section{References}

BERAN L., 2000: Aquatic molluscs (Gastropoda, Bivalvia) of the Litovelské Pomoraví Protected Landscape Area. - Acta Universitatis Palackianae Olomucensis, Biologica, 38: 17-28.
BERAN L., 2002: Vodní měkkýši České republiky rozširrení a jeho změny, stanoviště, šíření, ohrožení a ochrana, červený seznam [Aquatic molluscs of the Czech Republic - distribution and its changes, habitats, dispersal, threat and protection, Red List]. - Sborník prŕrodovědného klubu v Uh. Hradišti, Supplementum 10, 258 pp.

GLÖER P., 2002: Süsswassergastropoden Nord- und Mitteleuropas. - ConchBooks, Hackenheim, $327 \mathrm{pp}$.

MÁcHA S., 1963: Nové poznatky o malakofauně Hlučínské pahorkatiny [Neue Kenntnisse von der Wiechtierfauna des Hultschiner Hugellandes]. - Acta musei Silesiae, Series A, Opava, 12: 85-99.

MeIER-BrooK C., 1983: Taxonomic studies on $G y$ raulus (Gastropoda: Planorbidae). - Malacologia, 24 (1-2): 1-113.

PRUNER L. \& MíKA P., 1996: Seznam obcí a jejich částí v České republice s čísly mapových polí pro sít'ové mapování fauny [List of settlements in the Czech Republic with associated map field codes for faunistic grid mapping system]. - Klapalekiana, 32, Suppl.: 1-175.

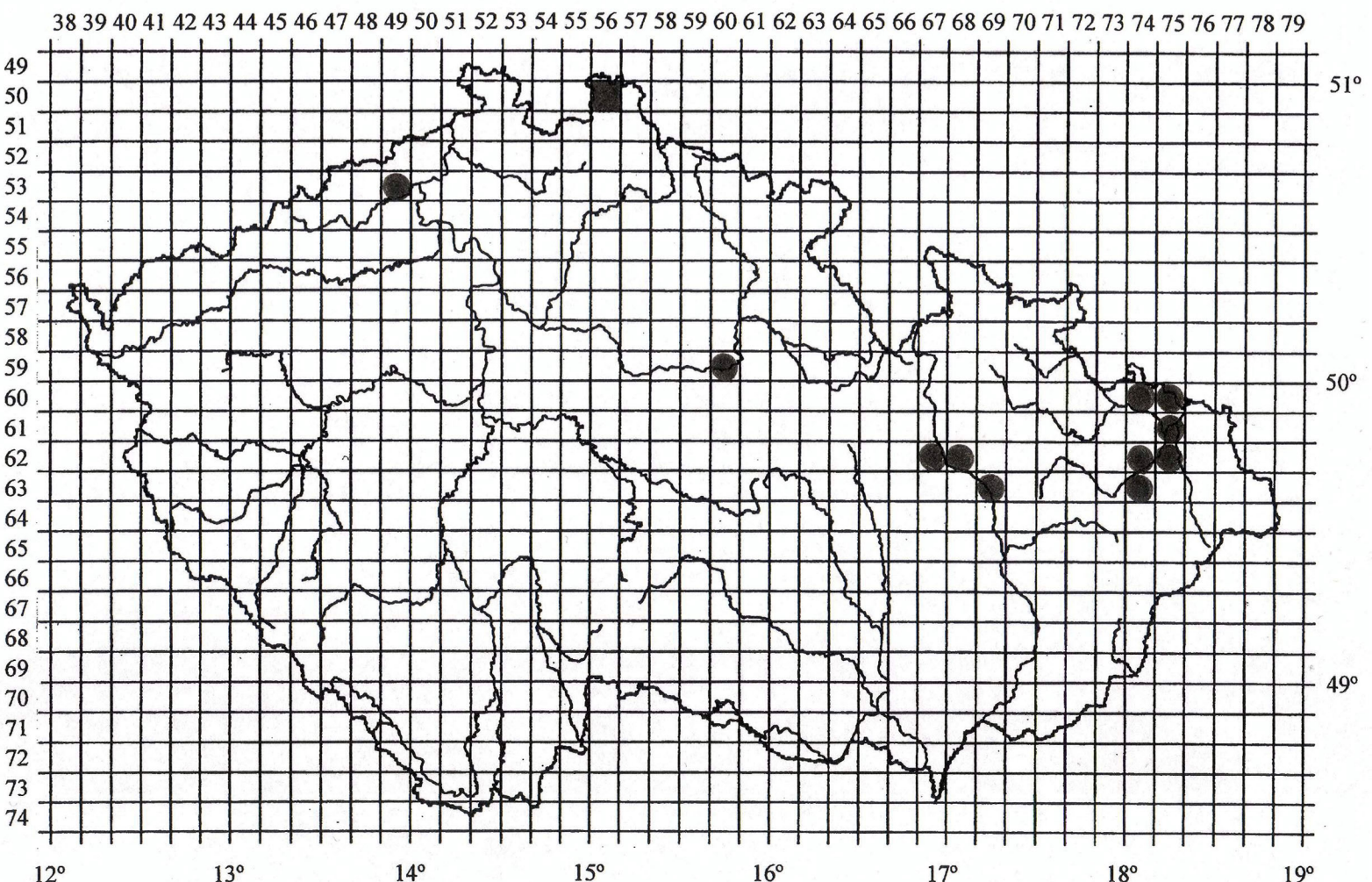

Fig. 1. The map for faunistic grid mapping with the known distribution of Gyraulus rossmaessleri in the Czech Republic. Full circle - adopted from BERAN (2002), full mapping field - new records mentioned above. 